\title{
PENYUSUNAN MODEL PERANGKAT LUNAK SEHATI ( SEHAT SUAMI DAN ISTRI ) \\ UNTUK MEMBANTU PEMILIHAN ALAT KONTRASEPSI YANG COCOK BAGI PASUTRI BERBASIS EXPERT SYSTEM
}

\author{
SM Santi Winarsih ${ }^{1}$, Retno Palupi ${ }^{2}$ \\ 1,2) Jurusan Teknik Informatika, Universitas Kristen Surakarta \\ ${ }^{1)}$ kshervida@yahoo.co.id, ${ }^{2)}$ rtnplp_2005@yahoo.com
}

\begin{abstract}
According to Muhammad Arhami (2005), Expert systems are computer programs that are designated as providers of advice and aids in problem solving in various areas of particular specialization. The main purpose of the expert system is not to replace the position of an expert or experts, but only to popularize the knowledge and experience of experts are very rare. With the help of an expert system even laymen can eventually use this expert system to solve problems and take decisions usually by an expert While the definition of contraception by Prof.Dr. Sarwono Prawiroharjo are attempts to prevent pregnancy. Efforts could be temporary, can also be permanent. Permanent sterilization or contraception can be called stable.The purpose of this research is to develop a software model SEHATI to assist with selection of suitable contraceptives for married couples-based expert system. With this program are expected to society could be helped choose a contraceptive that is safe and appropriate without having met with the officer kesehatab. For health workers themselves increasingly assisted in this socialization of the use of contraceptives. The stages are done in this study systematically is starting with the stage of literature to find references supporters then gather data, identify and konseptualisiasi to determine the limits of the problem and experts involved, then formalize include manufacturing knowledge base that relate to the topic, determining inference method, followed by making the database design, new hereinafter do modeling software SEHATI to assist with selection of appropriate contraception for married couples-based expert system.In addition to producing the software modeling SEHATI to assist with selection of suitable contraceptives for married couples-based expert system that enriches the scientific work, outcomes obtained from this study is the enrichment materials teaching materials on expert systems and local scientific journals.
\end{abstract}

Keywords: expert system, contraception, sterilization.

\section{PENDAHULUAN}

Menurut Prof.Dr. Sarwono Prawiroharjo laju pertumbuhan penduduk (Growth Rate) di tentukan oleh tingkat kelahiran dan tingkat kematian. Tingkat kelahiran kasar (Crude Birth Rate) dan tingkat kematian kasar (Crude Death Rate) masing-masing menunjukkan jumlah kelahiran hidup dan jumlah kematian per 1000 penduduk per tahun. Dengan demikian ada 4 kemungkinan dari 2 variabel ini, masing-masing (1) tingkat kelahiran tinggi dan tingkat kematian tinggi, (2) tingkat kelahiran tinggi dan tingkat kematian rendah, (3) tingkat kelahiran rendah dan tingkat kematian rendah, dan (4) tingkat kelahiran rendah dan tingkat kematian tinggi. Dengan perbaikan kesehatan, pelayanan dan pemakaian alat kontrasepsi lebih luas akan bisa menurunkan angka kematian dan angka kelahiran (Prawirohardjo \& Sarwono, 2005). 
Untuk meningkatkan kesejahteraan masyarakat khususnya di Indonesia pemerintah telah merencanakan dan mencanangkan program Keluarga Berencana (KB) yang diadakan untuk membina akseptor sekaligus mencapai sasaran/fungsi yang telah ditetapkan untuk memberi konstribusi bag tercapainya upaya mewujudkan keluarga berkualitas. Adapun pengertian dari KB yaitu tindakan yang membantu individu atau pasangan untuk menghindari kelahiran yang tidak diinginkan, mengatur interval kelahiran, mengontrol kartu keturunan dalam hubungan dengan umur pasanngan suami istri dan menentukan jumlah anak dalam keluarga (Hartanto, 2003).

Perlu adanya sosialisasi pentingnya pemakaian alat kontrasepsi ini untuk bisa mengatur kelahiran bayi, sehingga bisa mendukung program Keluarga Berencana yang sudah dicanangkan oleh pemerintah. Selain itu juga dengan adanya pengaturan dan pembatasan kelahiran juga akan menghasilkan generasi yang sehat dan berkualitas. Kurangnya pemahaman dan pengertian tentang alat kontrasepsi apa yang cocok bagi pasangan suami istri menjadi kendala, sehingga perlu adanya penyusunan model perangkat lunak SEHATI untuk membantu pemilihan alat kontrasepsi yang cocok bagi pasangan suami istri berbasis expert system.

Dengan adanya model ini nanti akan membantu masyarakat bisa melakukan konsultasi pemilihan alat kontrasepsi tanpa bantuan tenaga kesehatan terkait sehingga tidak perlu sungkan atau malu. Dan bagi petugas kesehatan juga akan lebih terbantu dengan semakin tersosialisasinya pemakaian alat kontrasespi yang cocok bagi pasutri.

\section{TINJAUAN PUSTAKA}

\subsection{Tahap-tahap Pembuatan Sistem Pakar}

Menurut Muhammad Arhami proses membuat sebuah sistem pakar melibatkan banyak unsur-unsur yang saling keterkaitan dan ketergantungan satu dengan yang lainya serta saling berinteraksi, yaitu seorang pakar atau sekumpulan pakar, sistem pakar, alat pengembang sistem pakar, Knowledge Engineer, dan pemakai.

Tahapan pengembangan sistem Pakar yaitu: (Aziz \& Farid, 1994),

1. Identifikasi

Identifikasi merupakan tahapan yang harus dilakukan pada tahap awal untuk mengidentifikasikan permasalahan yang akan dikaji. Diperlukan batasan masalah yang dikaji, pakar yang terlibat, dan tujuan yang akan dicapai.

2. Konseptualisasi

Merupakan tahap di mana suatu konsep dari sistem pakar yang akan dikembangkan seluruh unsur yang ada dirinci, kemudian akan dikaji hubungan yang ada antar unsur tersebut, dan mekanisme pengendalian yang diperlukan untuk mencapai solusi dalam memecahkan suatu masalah.

3. Formalisasi

Formalisasi merupakan tahapan di mana hubungan antara unsur-unsur digambarkan dalam bentuk format yang biasa digunakan dalam sistem pakar. Bentuk format tersebut bisa berupa struktur data dan teknik inferensi yang telah ditentukan. Pada tahap ini knowledge engineer akan menentukan alat pembangun sistem pakar yang akan digunakan. 
4. Implementasi

Setelah formalisasi telah usai maka saatnya menterjemahkan hubungan antar unsur-unsur ke dalam bahasa pemograman komputer tertentu sesuai apa yang telah dipilih.

5. Pengujian

Pengujian merupakan tahapan ketika tahap implementasi sudah selesai. Biasanya pada tahap ini akan dilakukan beberapa kali sampai dihasilkan sistem pakar yang handal. Sedangkan tahap akhir yaitu Pemeliharaan dan Perbaikan terhadap sistem pakar.

\subsection{Alat Kontrasepsi}

Kontrasepsi adalah suatu alat, obat atau cara yang digunakan untuk mencegah terjadinya konsepsi atau pertemuan antara sel telur dengan sel jantan (sperma) di dalam kandungan/rahim. Secara umum definisi ini sering digunakan, tetapi secara khusus tentu akan melibatkan beberapa macam factor dalam proses pencegahan ini. Untuk memahami keadaan tersebut maka akan diuraikan secara singkat dan padat beberapa jenis kontrasepsi yang sering digunakan di Indonesia dan sangat perlu dipahami oleh petugas/provider dalam memberikan konsultasi lapangan mengenai Keluarga Berencana (Llewellyn Derek, 2002). Atau dalam hal ini yang akan menjadi representasi pengetahuan dari sistem pakar. Dalam hal ini asumsi yang akan ikut KB adalah wanita usia subur ( WUS ).

1) Kondom

Sarung karet tipis penutup penis yang menampung cairan sperma pada saat pria ejakulasi.

Cara Kerja :

- Mencegah pertemuan spermatozoa/sel mani dengan ovum/sel telur pada waktu bersenggama.

- Penghalang kontak langsung dengan cairan terinfeksi

Tingkat keberhasilan/Efektivitas : $80-95 \%$

2) Pil KB

Hormon yang mengandung estrogen dan progesterone atau progesterone saja yang diminum setiap hari selama 21 hari atau 28 hari.

Cara Kerja :

- Menekan ovulasi yang akan mencegah lepasnya sel telur wanita dari indung telur

- Mengendalikan lendir mulut rahim sehingga sel mani/sperma tidak dapat masuk ke dalam rahim

- Menipiskan lapisan endometrium/selaput lendir di vagina

Tingkat keberhasilan/efektivitas : 92-99\%

Cara penggunaan :

- Pil pertama diminum pada hari kelima haid, seterusnya berturut-turut setiap hari satu pil. Jika pemakai lupa meminumnya 1 hari maka segera minum 2 tablet keesokan harinya. Jika lupa lebih dari 2 hari, pemakai harus meminumnya lagi setelah haid berikutnya, kecuali jika pemakai yakin sedang tidak hami.

3) Suntikan KB

Hormon progesteron yang disuntikkan ke bokong/otot panggul lengan atas setiap 3 bulan atau hormon estrogen yang disuntikkan setiap 1 bulan sekali 


\section{Cara Kerja :}

- Mencegah lepasnya sel telur dari indung telur wanita

- Mengentalkan lendir mulut rahim, sehingga sperma (sel mani) tidak masuk ke dalam rahim

- Menipiskan endometrium/selaput lendir sehingga tidak siap untuk kehamilan

Tingkat keberhasilan/Efektivitas : lebih dari 99\%

Cara penggunaan :

- Depo provera disuntikkan ke dalam otot (intra musculer) setiap 3 bulan sekali. Dengan kelonggaran batas waktu suntik, bisa diberikan kurang 1 minggu atau lebih 1 minggu dari patokan 3 bulan.

- Cyclofem disuntikkan setiap 4 minggu ke dalam otot (intra musculer)

4) AKBK (Alat Kontrasepsi Bawah Kulit) / Susuk/Implant

1 atau 6 kapsul (seperti korek api) yang dimasukkan ke bawah kulit lengan atas secara perlahan melepaskan hormon progesterone selama 3 atau 5 tahun Cara Kerja :

- Menghambat terjadinya ovulasi

- Menyebabkan endometrium/selaput lendir tidak siap untuk nidasi/menerima pembuahan

- Mempertebal lendir serviks/rahim

- Menipiskan lapisan endometrium/selaput lendir

Tingkat keberhasilan/efektivitas : 97-99\%

5) AKDR (Alat Kontrasepsi Dalam Rahim)

Alat kontrasepsi yang dimasukkan ke dalam rahim yang bentuknya bermacam-macam, terbuat dari plastic, plastic yang dililit tembaga atau tembaga bercampur perak yang dapat berisi hormone. Waktu penggunaannya bisa mencapai 10 tahun.

Cara Kerja :

- Mencegah masuknya spermatozoa/sel mani ke saluran tuba

- Lilitan logam menyebabkan reaksi anti fertilitas

Tingkat keberhasilan/Efektivitas : 99\%

Cara penggunaan :

IUD dapat dipasang pada saat haid pemakai menjelang berakhir

6) KONTAP Pria (Kontrasepsi Mantap)/Vasektomi/Medis Operatif Pria (MOP)

Kontrasepsi permanen laki-laki untuk mereka yang tidak menginginkan anak lagi. Dalam pelaksanaannya nanti, pemakai harus menandatangani surat persetujuan yang juga harus ditandatangani oleh istrinya.

Cara Kerja :

- Menghalangi transport spermatozoa/jalannya sel mani pria sehingga tidak dapat membuahi sel telur

Tingkat Keberhasilan/Efektivitas : lebih dari 99\%

7) KONTAP Wanita (Kontrasepsi Mantap)/Tubektomi/Medis Operatif Wanita (MOW)

Kontrasepsi permanen wanita untuk mereka yang tidak menginginkan anak lagi. Dalam pelaksanaannya nanti, pemakai harus menandatangani surat persetujuan yang juga harus ditandatangani oleh suaminya. 
Cara Kerja :

- Menghambat perjalanan sel telur wanita sehingga tidak dapat dibuahi oleh sperma

Tingkat keberhasilan/Efektivitas : lebih dari 99\%

8) MAL (Metode Amenore Laktasi)

Merupakan metode mencegah kesuburan pada ibu yang habis melahirkan dengan menyusui bayi / memberi ASI pada bayi selama 6 bulan terus menerus secara ekslusif (tidak memberikan makanan dan minuman selain ASI).

Cara kerja :

- Dengan memberikan ASI kepada bayi secara terus menerus maka akan menghentikan ovulasi / kesuburan.

Tempat pelayanan alat kontrasepsi dapat pada tempat-tempat berikut, seperti :

- Rumah sakit

- Klinik KB, Puskesmas yang mempunyai tenaga terlatih untuk melakukan pembedahan (Implan, MOP dan MOW)

- Apotik

- Kantor BKKBN lokal

- Dokter atau bidan swasta

\section{METODE PENELITIAN}

Tahapan yang dilakukan di dalam penelitian ini meliputi :

1. Tahapan Studi Pustaka

Mempelajari buku-buku pendukung dan bahan-bahan yang diperlukan dalam penyusunan model perangkat lunak SEHATI untuk membantu pemilihan alat kontrasepsi yang cocok bagi pasangan suami istri berbasis expert system.

Mencari informasi melalui jurnal yang dipublikasikan yang terkait dengan metode perancangan perangkat lunak yang berbasis expert.

Browshing di internet untuk memperluas wawasan yang berhubungan dengan topik penelitian.

2. Tahapan Pengumpulan data dan studi kelayakan

Menentukan komponen-komponen data pendukung yang berhubungan dengan penyusunan model perangkat lunak SEHATI untuk membantu pemilihan alat kontrasepsi yang cocok bagi pasangan suami istri berbasis expert system.

3. Membangun sistem pakar dengan tahapan sbb (Aziz \& Farid, 1994) :

- Tahapan Identifikasi \& Konseptualisasi

o Menentukan batasan masalah dalam hal ini proses pemilihan alat kontrasepsi yang cocok bagi pasangan suami istri berbasis expert system.

o Menetukan Pakar yang terlibat dalam penelitian ini yaitu dr. Kristanto Setyawan Kepala Puskesmas Tasikmadu Karanganyar.

o Adapun konsep yang akan dikembangkan dalam sistem pakar dalam penelitian ini adalah menanyakan gejala klinis yang dirasakan oleh user dalam bentuk beberapa pertanyaan sampai user mendapatkan hasil diagnose pada pemeriksaan pemilihan alat kontrasepsi yang cocok bagi pasangan suami istri serta saran yang dianjurkannya. 
- Tahapan Formalisasi

o Tahap formalisasi merupakan suatu tahap dimana hubungan antara unsur-unsur digambarkan dalam bentuk format yang biasa digunakan dalam sistem pakar.

o Meliputi pembuatan basis pengetahuan, metode inferensi dalam hal ini forward chaining dan perancangan basis data.

- Tahapan Penyusunan Model

o Penyusunan model perangkat lunak SEHATI untuk membantu pemilihan alat kontrasepsi yang cocok bagi pasangan suami istri berbasis expert system.

- Tahapan Pembuatan Laporan Akhir

o Melakukan evaluasi terhadap penyusunan model perangkat lunak SEHATI untuk membantu pemilihan alat kontrasepsi yang cocok bagi pasangan suami istri berbasis expert system yang sudah dibuat.

o Menyusun laporan

\section{HASIL DAN PEMBAHASAN}

\subsection{TAHAP IDENTIFIKASI}

Dalam tahap identifikasi akan ditentukan batasan masalahan yang akan dikaji, pakar yang terlibat dan tujuan yang akan dicapai.

\subsubsection{Batasan Masalah}

Selama ini pemilihan alat kontrasepsi yang cocok masih dilakukan secara manual dan sangat bergantung dengan petugas kesehatan sehingga diperlukan perangkat lunak yang bisa membantu permasalahan ini. Namun dengan kompleknya permasalahan ini sehingga pada penelitian kali ini lebih menekankan kepada penyusunan model perangkat lunak SEHATI untuk membantu pemilihan alat kontrasepsi yang cocok bagi pasangan suami istri berbasis expert system .Dan untuk periode penelitian berikutnya bisa dilanjutkan dengan implementasi dari hasil penyusunan model ini.

Adapun konsep yang akan dikembangkan sistem pakar dalam penelitian ini adalah menanyakan gejala klinis yang dirasakan oleh user dalam bentuk beberapa pertanyaan sampai user mendapatkan hasil diagnose pada pemeriksaan pemilihan alat kontrasepsi yang cocok bagi pasangan suami istri serta saran yang dianjurkannya.

\subsubsection{Pakar yang terlibat}

Dalam penelitian ini pakar yang terlibat adalah dr Kristanto Setyawan. Beliau adalah Kepala Puskesmas Tasikmadu Karanganyar (pada saat pengajuan proposal beliau masih bertugas di Puskesmas Jatipuro Karanganyar, namun mulai bulan Januari 2016 dipindah tugaskan di Puskesmas Tasikmadu Karanganyar). Dan referensi buku tentang penyakit kehamilan, serta ditambah dari berbagai sumber atau artikel di internet.

\subsubsection{Tujuan}

Secara umum, penelitian ini bertujuan untuk membuat model perangkat lunak SEHATI untuk membantu pemilihan alat kontrasepsi yang cocok bagi pasangan suami istri berbasis expert system sehingga dapat digunakan untuk mengatur jumlah dan jarak kelahiran buah hati. 


\subsection{TAHAP KONSEPTUALISASI}

Tahap konseptualisasi merupakan suatu tahap dimana tahapan ini akan menentukan konsep yang akan dikembangkan untuk menjadi suatu sistem pakar. Tahapan ini juga merupakan perkembangan dari tahap identifikasi. Setelah mendapatkan batasan masalah yang dikaji dan pakar yang terlibat. Dengan adanya model ini nanti akan membantu masyarakat bisa melakukan konsultasi pemilihan alat kontrasepsi tanpa bantuan tenaga kesehatan terkait sehingga tidak perlu sungkan atau malu. Dan bagi petugas kesehatan juga akan lebih terbantu dengan semakin tersosialisasinya pemakaian alat kontrasespi yang cocok bagi pasutri.

Adapun konsep yang akan dikembangkan sistem pakar dalam penelitian ini adalah menanyakan gejala klinis yang dirasakan oleh user dalam bentuk beberapa pertanyaan sampai user mendapatkan hasil diagnose pada pemeriksaan pemilihan alat kontrasepsi yang cocok bagi pasangan suami istri serta saran yang dianjurkannya. Karena metode yang dikembangkan adalah forward chaining maka dalam hal ini proses pelacakan berawal dari pertanyaan tentang gejala yang dirasakan pasutri baru kemudian akan ditentukan alat kontrasepsi yang cocok serta saran yang sesuai dengan hasil kesimpulan yang diperoleh.

\subsection{TAHAP FORMALISASI}

Tahap formalisasi merupakan suatu tahap dimana hubungan antara unsurunsur digambarkan dalam bentuk format yang biasa digunakan dalam sistem pakar. Adapun kompenen sistem pakar terdiri dari 4 bagian sbb(Hartanti, Iswati, 2008) :

\subsubsection{Basis Pengetahuan (Knowledge Base)}

Basis pengetahuan merupakan representasi pengetahuan (Knowledge Base) dari seorang pakar. Basis pengetahuan ini tersusun fakta yang berupa informasi tentang obyek, dan kaidah (rule), yang merupakan informasi tentang cara bagaimana membangkitkan fakta baru dari fakta yang sudah diketahui. Salah satu metode terbaik adalah menggunakan penelitian pengalaman yang panjang melalui kaidah atau aturan produksi (IF - THEN).

Basis pengetahuan ini diperoleh pada saat proses wawancara atau akuisisi langsung dengan pakar yaitu dokter Kristanto Setyawan dan dibantu juga oleh petugas kesehatan. Selain juga juga berasal dari proses observasi yang peneliti lakukan. Basis pengetahuan ini nanti disusun dengan berdasarkan metode inferensi seperti pada bahsan selanjutnya.

\subsubsection{Mesin Inferensi (Inference Engine)}

\section{a. Pohon Keputusan (Decision Tree)Pemilihan Alat Kontrasepsi}

Suatu tree (pohon) adalah suatu hierarki struktur yang terdiri dari node (simpul) yang berisi informasi atau pengetahuan dan cabang (link) yang menghubungkan node. Node paling bawah disebut daun berisi kesimpulannya. Pada penelitian ini pohon keputusan (Gambar 1) dibuat untuk memudahkan pembuatan kaidah produksi, dimana node berisi pertanyaan, cabangnya berisi jawaban ya atau tidak untuk menjawa pertanyaan dan daun (node paling bawah ) berisi kesimpulan pertanyaan alat KB apa yang cocok. 


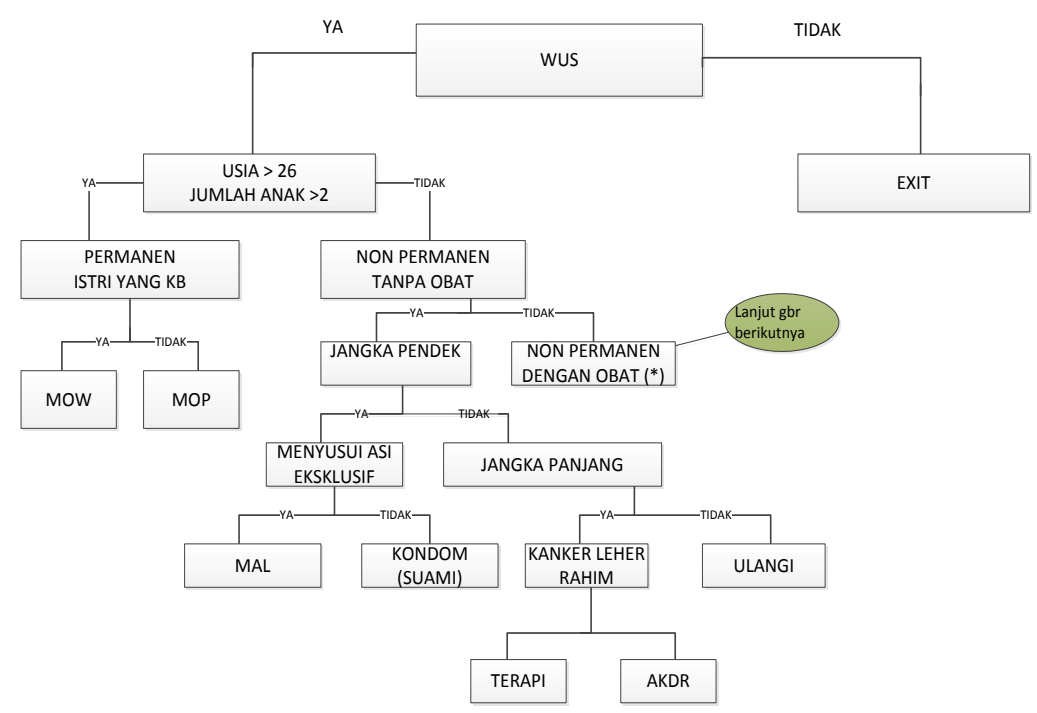

Gambar 1. Pohon Keputusan Pemilihan Alat Kontrasepsi Tanpa Obat

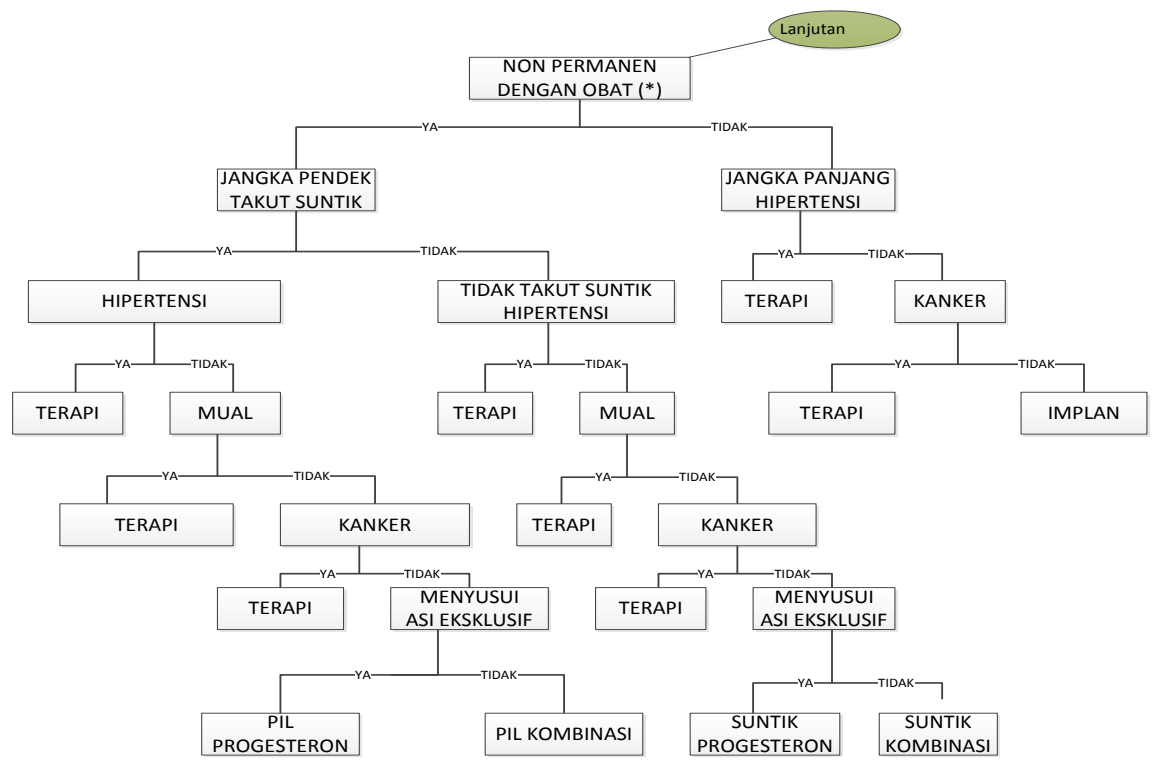

Gambar 2. Pohon Keputusan Pemilihan Alat Kontrasepsi Dengan Obat

Struktur keputusan dapat diterjemahkan secara mekanis ke dalam kaidah produksi (production rule) yaitu IF... THEN ( jika...maka). Sebagai contoh dimulai dari gambar $4.2 \mathrm{sbb}$

JIKA pertanyaan $=$ ' Apakah usia $>26$ dan Jumlah anak $>2$ ?'

DAN Jawaban ='ya"'

MAKA Pertanyan =' Apakah Permanen dan istri yang KB ?

DAN Jawaban $=$ 'Ya"

MAKA Kesimpulan ='MOW"'

Dan seterusnya untuk node-node lainnya. Node daun akan memberikan jawaban sebagai respons dari pertanyaan.

\subsubsection{Rancangan Basis Data}

Basis data adalah sekumpulan data yang saling berhubungan secara logis dan terorganisir dengan baik (Pahlevi \& Said, 2013). Rancangan basis data pada penelitian ini sbb : 


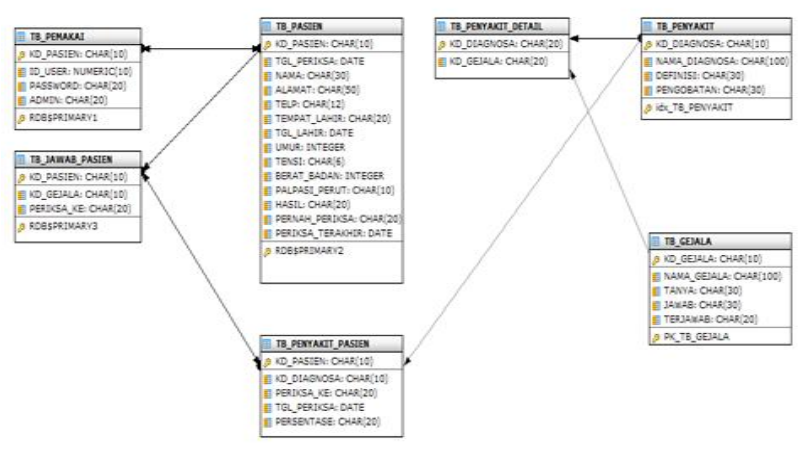

Gambar 3. Hubungan Antar Tabel (Relationships)

\subsubsection{Perancangan Interface}

\subsubsection{Rancangan Menu Utama}

Menu utama meliputi menu login, master, konsultasi, data, laporan dan menu about. Menu master terdiri dari data pasien dan data user. Menu konsultassi hanya terdiri dari proses pertanyaan sampai ditemukan solusi. Menu laporan terdiri dari laporan data pasien, laporan data user, laporan data alat kontrasepsi dan laporan solusi alat kontrasepsi yang cocok bagi pasutri. Kemudian yang terakhir menu about terdiri dari about pakar dan about pembuat program (programmer). User interface menu utama dapat dilihat pada Gambar 4.

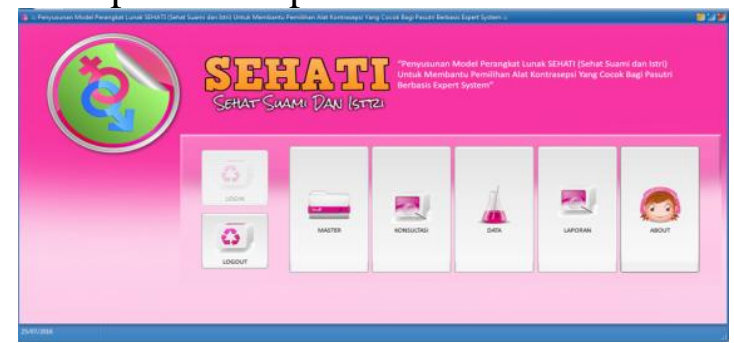

Gambar 4. Perancangan Menu Utama

\subsubsection{Rancangan Menu Konsultasi}

Menu konsultasi seperti pada Gambar 5 digunakan oleh pasien ( pasutri) yang ingin mengetahui alat kontrasepsi apa yang cocok. Pasien harus input data dahulu kemudian baru masuk ke jendela selanjutnya yang berupa pertanyaan-pertanyaan yang harus dijawab oleh pasien sesuai dengan kondisinya saat itu. Semua pertanyaan harus dijawab agar didapatkan solusi berupa alat kontrasepsi apa yang harus dipilih.

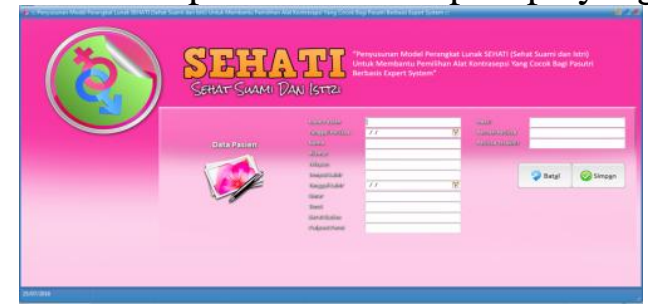

Gambar 5. Perancangan Menu Konsultasi

\subsubsection{Rancangan Menu User}

Menu user digunakan untuk menentukan hak akse antara user dan admin (pakar), karena hanya seorang pakar yang nantinya bisa update di 
knowledgebasenya. Sedangkan pasien (user) hanya diberi hak akses untuk konsultasi saja. Dan melihat hasilnya di laporan

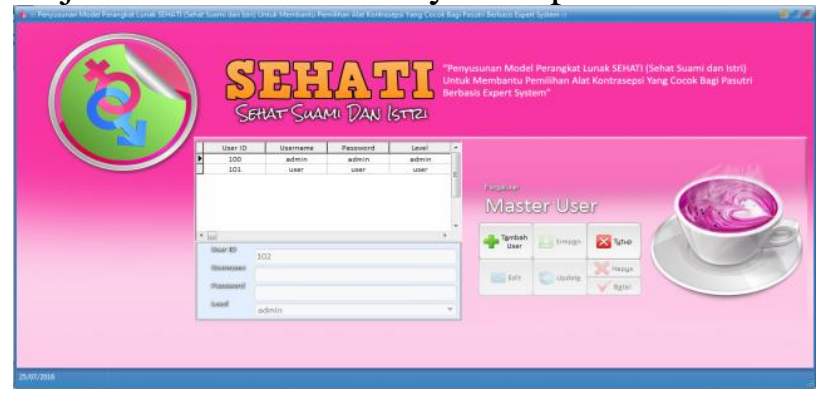

Gambar 7. Perancangan Menu User

\section{KESIMPULAN DAN SARAN}

\subsection{KESIMPULAN}

- Dengan adanya perancangan prototype ini akan dapat membantu pada saat tahapan implementasi selanjutnya.

- Hasil wawancara dengan pakar sudah dapat digunakan untuk membuat rule secara kesuluruhan sehingga sudah bisa di kelompokan setiap kondisi dan jenis alat kontrasepsi yang yang cocok bagi pasutri.

- Perancangan ini nantinya akan bisa membantu petugas medis dalam melaksanakan tugasnya.

- Tabel pohon keputusan akan sangat membantu dalam proses pembuatan rule selanjutnya.

\subsection{SARAN}

- Segera dilanjutkan ke tahapan selanjutnya sehingga bisa memberikan banyak manfaat

- Implementasinya dibuat berbasis web sehingga akan bisa di akses oleh banyak orang tanpa harus ketemu pakar terkait.

- Implementasi selanjutnya bisa berbasis mobile sehingga mudah di akses oleh siapa saja, kapan saja dan dimana saja.

\section{DAFTAR PUSTAKA}

Arhami, \& Muhammad. (2005). Konsep Dasar Sistem Pakar. Yogyakarta: Andi Offset.

Aziz, \& Farid. (1994). Belajar Sendiri Pemrgraman sistem Pakar. Jakarta: PT Elex Media Komputindo.

Hartanto, H. (2003). Keluarga Berencana dan Kontrasepsi. Jakarta: CV. Mulia Sari.

Hartati, Sri, \& Iswanti, S. (2008). Sistem Pakar \& Pengembangannya. Yogyakarta: Graha Ilmu.

Llewellyn Derek, J. (2002). Dasar-dasar Obstetri \& Ginekologi. Alih bahasa :dr Handoyo. Jakarta: Hipokrates.

Pahlevi, \& Said, M. (2013). Tujuh Langkah Praktis Pembangunan Basis Data. Jakarta: PT Elex Media Komputindo.

Prawirohardjo, \& Sarwono. (2005). Ilmu Kandungan. Jakarta: YBP-SPEd: Pearson Education, Inc. 